\title{
Wolf-dog hybridization in Croatia
}

\section{Josip Kusak ${ }^{1 *}$, Elena Fabbri², Ana Galov ${ }^{3}$, Tomislav Gomerčić ${ }^{1}$, Haidi Arbanasić ${ }^{3}$, Romolo Caniglia' ${ }^{2}$, Marco Galaverni' ${ }^{2}$, Slaven Reljić ${ }^{1}$, Djuro Huber ${ }^{1}$, and Ettore Randi ${ }^{2}$}

\author{
${ }^{\prime}$ Department of Biology, Faculty of Veterinary Medicine, University of Zagreb, Zagreb, Croatia \\ ${ }^{2}$ Area per la Genetica della Conservaizone, Istituto Superiore per la Protezione e Ricerca Ambientale \\ (ISPRA), Ozzano dell'Emilia (Bo), Italy \\ ${ }^{3}$ Department of Biology, Faculty of Science, University of Zagreb, Zagreb, Croatia
}

\section{KUSAK, J., E. FABBRI, A. GALOV, T. GOMERČIĆ, H. ARBANASIĆ, R. CANIGLIA, M. GALAVERNI, S. RELJIĆ, DJ. HUBER, E. RANDI: Wolf-dog hybridization in Croatia. Vet. arhiv 88, 375-395, 2018.}

\section{ABSTRACT}

Wolf-dog hybridization is considered as one of the main threats for wolf conservation since the admixture and introgression of domestic genes may disrupt local adaptations and threaten the long term survival of wild wolf populations. We investigated the occurrence of wolf-dog hybridization in Croatia by analyzing a panel of 12 autosomal microsatellite markers using Bayesian admixture tests, and assessed its directionality by the use of maternally and paternally inherited markers in combination with morphometric data and morphological features. A systematic analysis of morphologic features and morphometric data was used to rank the studied individuals into either phenotypic wild-type wolves or suspected hybrids. By combining Bayesian assignment results with phenotypic features, we set three thresholds which differentiated wolves from hybrids with maximized hybrid detection and a minimized chance for false positive hybrid identification. On the basis of phenotype, out of 176 wild canids, $157(89.2 \%)$ were categorized as wolves and $19(10.8 \%)$ as suspected hybrids. On the basis of the Bayesian admixture tests and phenotype together, five ( 2.8 percent) animals were classified as wolf-dog hybrids, four of them as backcrosses with wolves, and one as a backcross with a dog. Mitochondrial DNA suggested that all hybrids originated from the mating of female wolves and male dogs. Two male hybrids had Y chromosome haplotypes common to both wolves and dogs, while the other two had wolf private $\mathrm{Y}$ chromosome haplotypes. One wolf had a dog Y-haplotype, indicating a past introgression of dog genes. All hybrids were found in Dalmatia, where wolves settled recently, and where they live close to humans, with a high rate of human-caused mortality. These conditions are considered as favorable for wolf-dog hybridization. However, we found a low hybridization prevalence in Croatia, which is nonetheless expected to persist as long as the conditions favoring its occurrence are met. The ecological, sociological, conservation and management implications of hybrid occurrence are yet to be determined.

Key words: wolf; dog; Canis lupus; hybridization; Croatia; Bayesian admixture analysis; microsatellites; parental markers

\footnotetext{
*Corresponding author:
}

Dr. sc. Josip Kusak, DVM, Department of Biology, Faculty of Veterinary Medicine, University of Zagreb, Heinzelova 55, 10000 Zagreb, Croatia, Phone: +385 12390 142; E-mail: kusak@vef.hr 


\section{Introduction}

Wild canids (genus Canis) can naturally hybridize amongst themselves (WAYNE et al., 1997) and also with domestic dogs (C. lupus familiaris), which were domesticated from gray wolves (C. lupus) in a process which started more than 27000 years ago (SKOGLUND et al., 2015). The divergence of dogs from wolves was completed between 11000 to 16000 years ago (FREEDMAN et al., 2014). Wolf-dog hybridization is considered to be one of the main threats to wolf conservation, since the admixture of domestic genes may disrupt local adaptation (VILÀ and WAYNE, 1999) and thus threaten the long term survival of wild wolf populations (BOITANI, 2003). The chances for wolf-dog hybridization are considered to be higher in areas where wolves live close to settlements with a high density of dogs (BLANCO et al., 1992), in situations when wolves are heavily victimized (RANDI et al., 2000), or during the expansion phase of the wolf population (LORENZINI et al., 2014). One of the first extensive studies of wolf-dog hybridization did not find widespread hybridization in European gray wolf populations in contrast to the rather high prevalence (8-17\%) of hybrids in Ethiopian wolves (VILÀ and WAYNE, 1999). Sexual asymmetry (the prevalence of female gray wolf over male dog hybrids), and physiological and behavioral differences between gray wolves and dogs have been recognized as reasons for the low detected prevalence of hybrids, particularly when maternally inherited markers (mitochondrial DNA) were analyzed (VILÀ and WAYNE, 1999). The advances in research techniques brought increasing evidence that hybridization between gray wolves and dogs exists in Europe in Bulgaria, Serbia, Latvia and Estonia (RANDI et al., 2000; MILENKOVIĆ et al., 2006; HINDRIKSON et al., 2012) and particularly in Italy (RANDI and LUCCHINI, 2002; LORENZINI et al., 2014; RANDI et al., 2014). Such findings may render wolf-dog hybridization to be one of major wolf conservation challenges, not only in Italy, but also in wolf populations in other countries with a similar history, status and ecological conditions for wolves, such as Croatia.

Wolves inhabited the whole of Croatia until the end of $19^{\text {th }}$ century, but systematic eradication confined them to mountainous areas of Gorski kotar and Lika (about 10000 $\mathrm{km}^{2}$ ), with numbers declining to only 30-50 individuals in the late 1980s (FRKOVIĆ and HUBER, 1992). At the beginning of 1990s, the Croatian wolf population started to grow and reached about 200 individuals by 2010, expanding to areas of Dalmatia, Banovina and Učka, comprising about $18.000 \mathrm{~km}^{2}$ in total (KUSAK and HUBER, 2010a). In spite of the legal protection since 1995 (ŠTRBENAC et al., 2005), a monitoring program revealed a high proportion of human caused mortality in Croatian wolves (HUBER et al., 2002; KUSAK and HUBER, 2010b). Wolf management plans recognize hybridization between protected wolves and domestic dogs as a possible threat, but marginal management attention was dedicated to this phenomenon since its actual impact on the Croatian wolf population still remains poorly known (ŠTRBENAC et al., 2010). 
This study was thus planned in order to investigate if wolf-dog hybridization really occurs in Croatia and if it does, what the prevalence is of hybrids in the wild population, their spatial distribution and the main directionality of hybridization events.

\section{Materials and methods}

We collected 176 samples of wolves (W) or suspected wolf-dog hybrids (SH) from Gorski kotar (GK; $n=42)$, Lika (L; $n=46$ ), Dalmatia (DA; $n=80$ ), Banovina (B; $n=$ 2), the Panonian part of Croatia (P; $n=1)$ and Bosnia \& Herzegovina (B\&H; $n=5$, close to the border with Dalmatia), in the period from 1996 to 2011 (Fig. 1). Samples from Banovina and Panonia were merged with samples from Gorski kotar, while samples from B\&H were joined to samples from Dalmatia. We also collected 49 samples of dogs (D) from the same areas where wolf samples were collected. All samples were collected as part of the wolf monitoring program (ŠTRBENAC et al., 2010) when dead wolves (traffic accidents, shot legally and illegally, dead due to diseases) and wolves captured alive for telemetry tracking (KUSAK et al., 2005; KUSAK, 2010) were externally examined and measured for 23 body parameters, as in PLATIŠA et al. (2011). The body measurements of the wolves and suspected hybrids were compared with the average measurements of wolves of the same age and gender category determined by PLATIŠA et al. (2011) from 149 "pure" (i.e. without any apparent morphological deviations) Croatian wolves. All measurements that differed more than 1SD from the average for corresponding age and gender category were considered morphometric differences. The phenotypic anomalies (morphometric differences and morphological deviations) which we considered in distinguishing wolves from suspected hybrids were: 1) absence of black stripes on the front legs in combination with at least one more atypical features, 2) connected posterior ends of the $3^{\text {rd }}$ and $4^{\text {th }}$ digits on the paws, in a combination with at least one more atypical feature, 3) flat forehead, i.e. almost no "step" between the cranium and nose, 4) short or long head 5) long and narrow nose, 6) length asymmetry between the upper and lower jaws, 7) presphenoid bone on the base of the skull without lateral "wings", but simple and spiky as in dogs, 8) slightly concave muzzle (snout), i.e. saddle-like, 9) too small or too wide a distance between the left and right upper and/or left and right lover canines, 10) long ears, 11) small paws, 12) small body mass, and then, as in RANDI et al. (2014), 13) the presence of dewclaw, 14) dog-like body shape (a combination of short legs with rounded, barrel-like body), 15) atypical coat coloration including black, yellow, patchy or completely white coat and claws (albinism).

The DNA of wolves, suspected hybrids and dogs was extracted, PCR-amplified and genotyped for twelve autosomal microsatellites (STR) and four Y-linked STR haplotypes, following the methodology described in FABBRI et al., 2014. Partial sequences (280 bp) of the hypervariable part of the mitochondrial DNA control-region (mtDNA CR1) were obtained using the PCR primers CR1 and CR2R, as described in GOMERČIĆ et al., 


\section{J. Kusak et al.: Wolf-dog hybrids in Croatia}

(2010). Procedures for aligning and collapsing identical mtDNA sequences, and matches with sequences in GenBank, were done as in FABBRI et al. (2014).

The software STRUCTURE v2.3.4 (FALUSH et al., 2007) was used to assign samples to the wolf or dog group, and to identify genetic signals of hybridization or introgression of domestic genes in the wolf population. The models implemented in STRUCTURE are based on Bayesian statistics. The software, inferring population structure, assigns individuals to clusters, independent of any prior non-genetic information. The run parameters used in STRUCTURE were the following: "admixture" and independent allele frequency " $I$ " models, without any prior population information, assuming $K$ from 1 to 5. Three independent runs were done for each $K$ using 400,000 of the Monte Carlo Markov chain (MCMC) and discarding the first 40,000 of burn-ins. The $\Delta K$ statistics were used to identify the highest rate of increase in the posterior probability $\operatorname{LnP}(\mathrm{D})$ of the data between each consecutive $K$. Following RANDI et al., 2014, the power of admixture analyses to detect $F_{1}$ and $F_{2}$ hybrids, first and second generation of backcrosses, given the number of markers and the level of genetic differentiation between parental populations (estimated by $F_{\text {st }}$ ), was assessed by simulation (VÄH ̈̈ and PRIMMER, 2006). We randomly selected two groups of parental genotypes (43 wolves and 43 dogs with individual $q_{\mathrm{i}}$ values $>0.980$ ) to generate 200 individuals in each parental ( $\mathrm{PD}$ and $\mathrm{PW}$ ), $F_{1}, F_{2}$ and backcross $\left(\mathrm{BC}_{1} \mathrm{D}, \mathrm{BC}_{2} \mathrm{D}, \mathrm{BC}_{1} \mathrm{~W}, \mathrm{BC}_{2} \mathrm{~W}\right)$ genotype classes with the software HYBRIDLAB v1.0 (NIELSEN et al., 2006). Hybrid genotypes were created by random sampling alleles from their frequency distributions in the parental populations, assuming neutrality, linkage equilibrium and random mating. Then the simulated genotypes were used to carry out admixture analyses with STRUCTURE v.2.3.4 and the qi values for the different simulated hybrid classes were compared with the sampled individuals.

The simulated genotypes were analyzed in the assignment procedure running STRUCTURE as follows: 1) Only parental populations (PW, PD, $\mathrm{n}=400$ individuals), $K=2$, "admixture" and "I" models; 2) Parental populations and all 6 classes of hybrid genotypes ( $\mathrm{n}=1600), K=2$, "admixture" and "I" models; 3 ) Parental populations and all 6 classes of hybrid genotypes $(\mathrm{n}=1600), K=2$, "population information" (POPINFO) and " $I$ " models.

To identify wolf-dog hybrids we used three thresholds predetermined by the results obtained using simulated hybrid genotypes. To maximize hybrid detection but minimize false positives (wolves erroneously identify as hybrids) we fixed the following rules for the chosen thresholds: 1) lower $q$ i values observed in parental simulated populations; 2) the highest $q \mathrm{i}$ in $\mathrm{F}_{2}$ hybrids; 3) lower $q \mathrm{i}$ values observed in the parental wolf population PW (obtained analyzing only Parental populations in STRUCTURE), to be used for individuals with only phenotypic anomalies. Spatial distribution analysis and data representation of the collected samples were done with the use of ArcGIS Desktop ver. 10.3 (ESRI Inc.). 


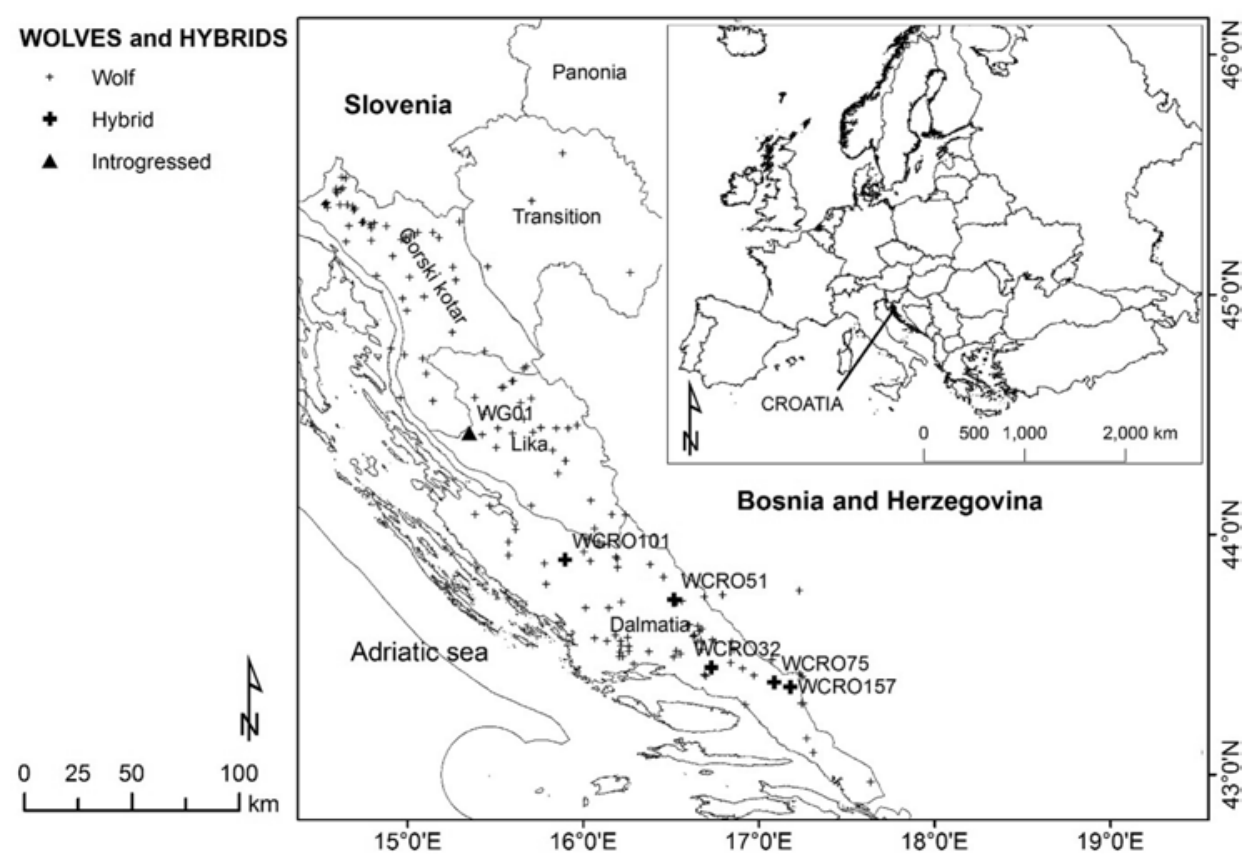

Fig. 1. Spatial distribution of wolves and wolf-dog hybrids found in Croatia in the period from 1996 to 2011. All genetically determined hybrids were found in Dalmatia, while one animal from the Lika region showed a dog Y-haplotype but no other genetic (12-STR, mtDNA CR1) or phenotypic signals of hybrid origin, and therefore was classified as a wolf with introgressed dog genes.

\section{Results}

The analysis of phenotypic anomalies allowed us to identify $157(89.2 \%)$ of the 176 wild canids ( 78 females, 95 males and three of undetermined gender) as wolves and $19(10.8 \%)$ as suspected hybrids. The most frequent anomaly was atypical coat color $(n=11)$, then the absence of black stripes on the front legs $(n=5)$, followed by a long head $(n=4)$, long ears $(n=4)$, flat forehead $(n=3)$, while connected $3^{\text {rd }}$ and $4^{\text {th }}$ digits, short head, saddle shape nose, and small body mass were found twice, and small paws, dog-like body shape, small distance between canines, asymmetrical jaws and dog-like presphenoid bone, were found once (Table 1). These phenotypic anomalies were found in different combinations in different animals. The phenotypic anomalies found were further illustrated by photographs of some of the suspected hybrids (Fig. 2 and Fig. 3) and determined hybrids (Fig. 4). 
J. Kusak et al.: Wolf-dog hybrids in Croatia

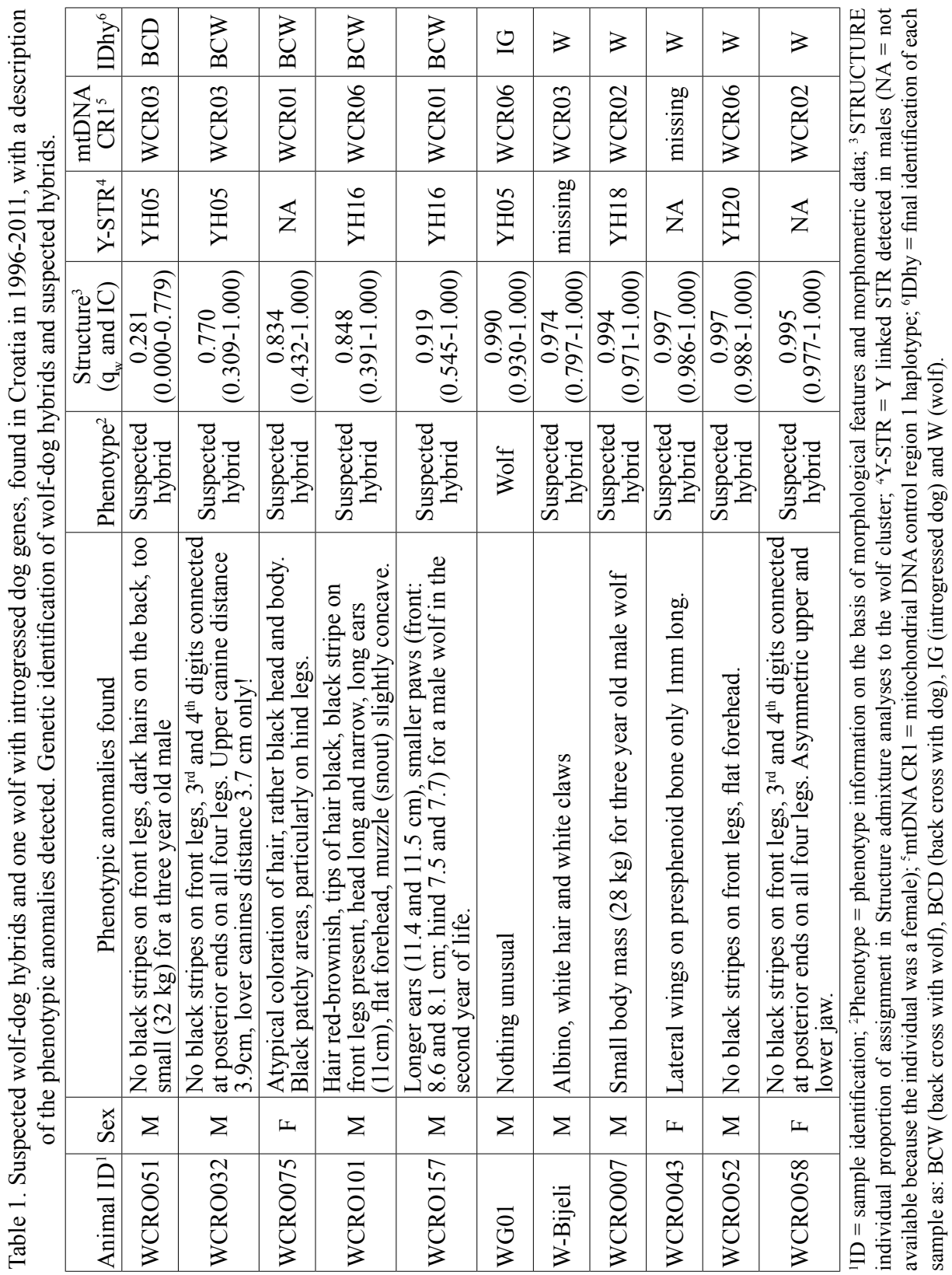


J. Kusak et al.: Wolf-dog hybrids in Croatia

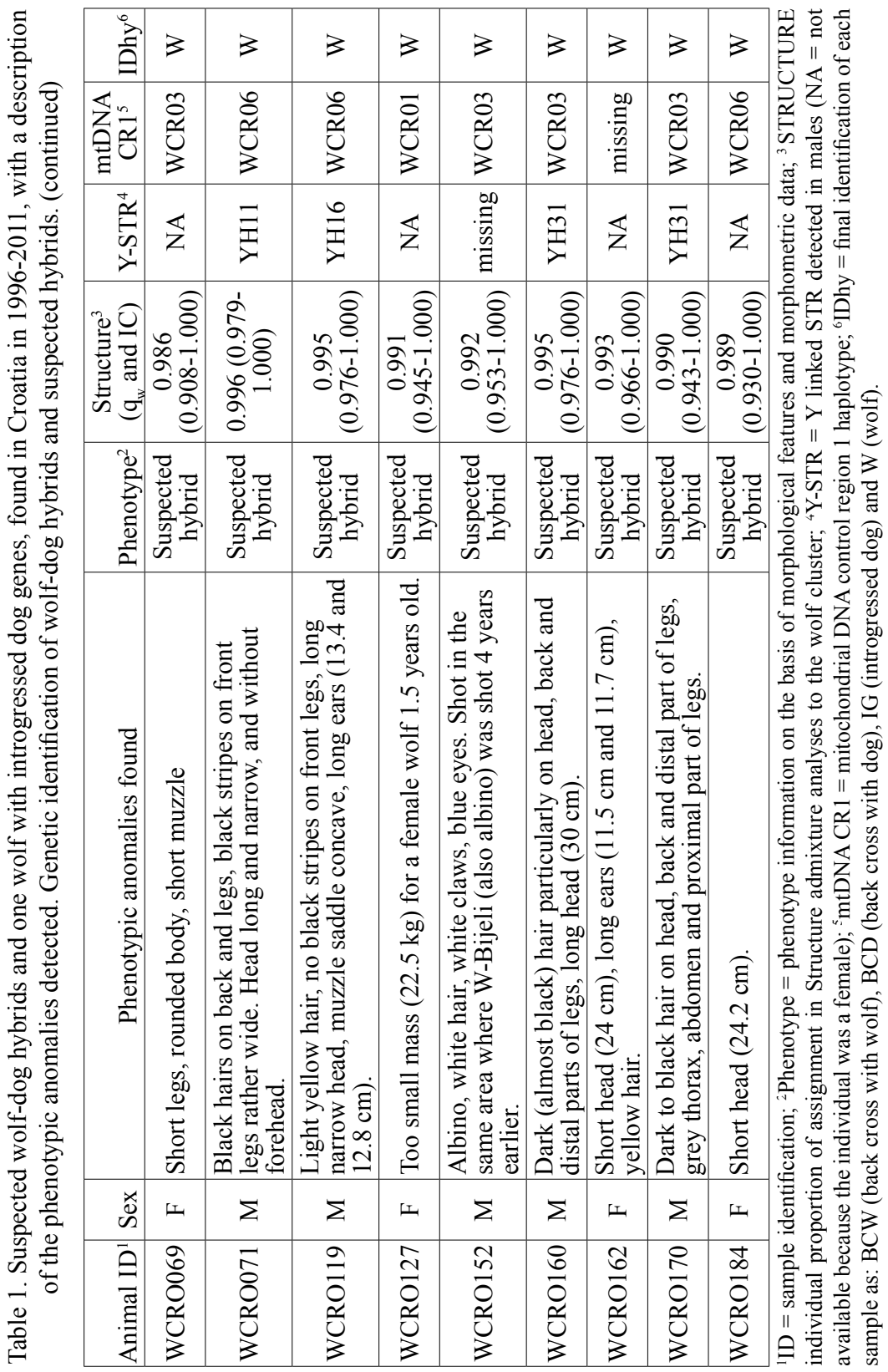

Vet. arhiv 88 (3), 375-395, 2018 


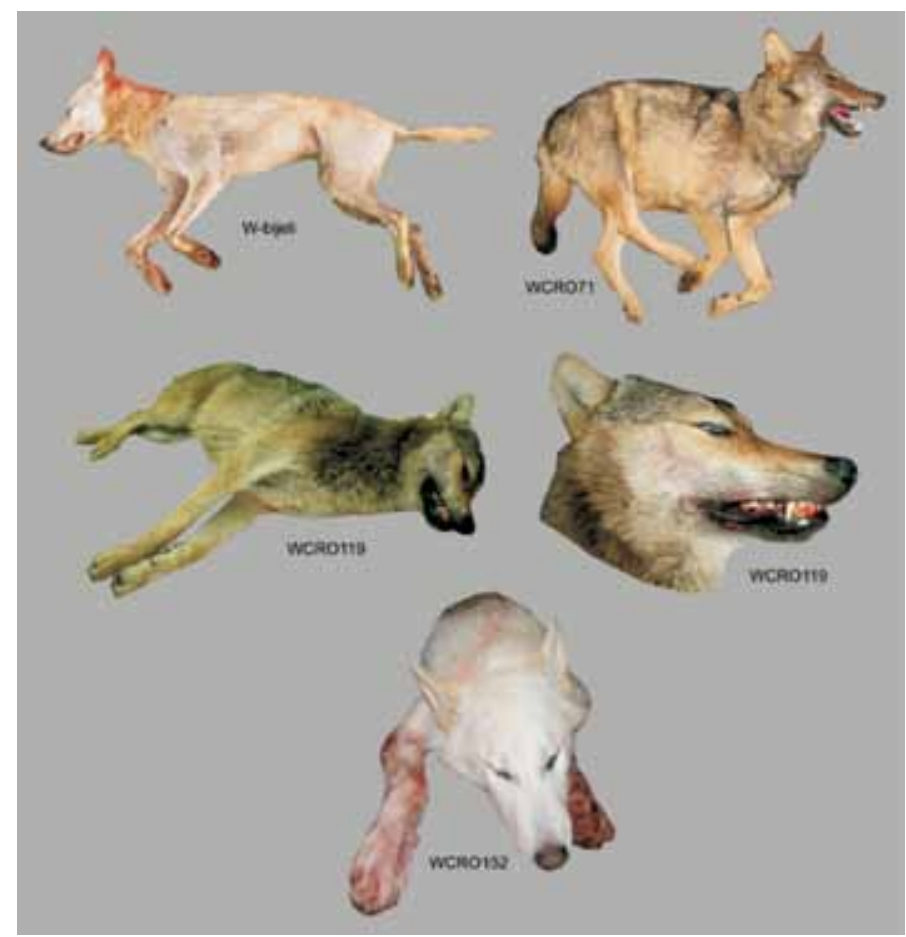

Fig. 2. Suspected wolf-dog hybrids, but genetically classified as wolves, found in Croatia in the period 1996-2011. Combinations of phenotypic anomalies shown include: albinism (W-Bijeli and WCRO152), head long and narrow, and without forehead (WCRO71), light yellow hair, no black stripes on front legs, long narrow head, muzzle saddle concave, ears 13.4 and $12.8 \mathrm{~cm}$ long (WCRO119).

Out of 49 examined dogs (D), 25 (51.0\%) were males, and out of 157 phenotypic wolves $95(60.5 \%)$ were males, while for three $(1.9 \%)$, gender was not determined. Based on their phenotype, out of 95 wild male canids, 83 were classified as wolves (W), while 12 were classified as suspected hybrids $(\mathrm{SH})$. For 18 males $(\mathrm{D}=3, \mathrm{~W}=13, \mathrm{SH}=2)$ Y-STR was not determined. The distribution of Y-STR for the remaining 105 males is shown in Table 2, and compared with the findings of the same Y-STR haplotypes found by other studies in dogs, wolf-dog hybrids and in other wolf populations in Europe and Russia (SUNDQVIST et al., 2001; IACOLINA et al., 2010; RANDI et al., 2014).

A total of ten Y-STR haplotypes were found in dogs from Croatia, and eight of them were private, i.e. not found in wolves or suspected hybrids from Croatia. Three Y-STR haplotypes were found as new in dogs (Table 2). In groups of phenotypic wolves and suspected hybrids, eleven and six different Y-STR haplotypes were found, respectively. 
Phenotypic wolves and suspected hybrids carried nine private Y-linked STR haplotypes. The haplotypes common to dogs and wolves were YH05 and YH08. Haplotype YH05 was the most common in dogs $(\mathrm{n}=11)$, but it was found in one phenotypic wolf and in two suspected hybrids, while YH08 was found eleven times in phenotypic wolves and only once in dogs.

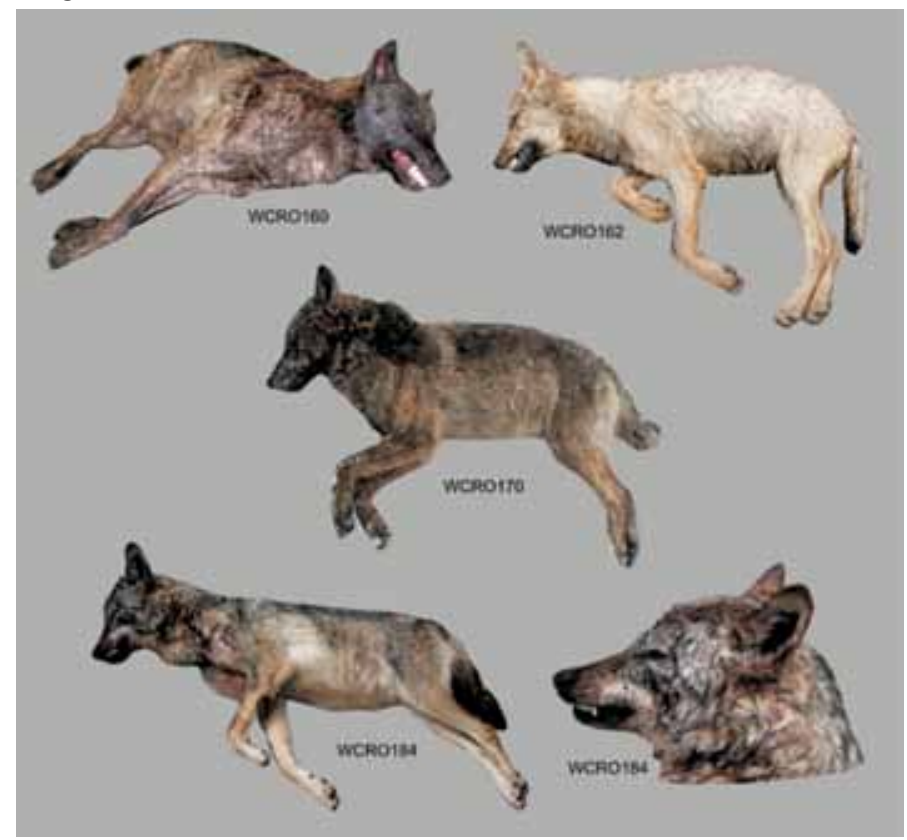

Fig. 3. Suspected wolf-dog hybrids, but genetically classified as wolves, found in Croatia in the period 1996-2011. Combinations of phenotypic anomalies shown include: dark (almost black) hair particularly head, back and distal parts of legs (WCRO160 and WCRO170), plus $30 \mathrm{~cm}$ long head (WCRO160), short head $(24 \mathrm{~cm})$, long ears $(11.5 \mathrm{~cm}$ and $11.7 \mathrm{~cm})$, yellow hair, all found in

WCRO162, while short head $(24.2 \mathrm{~cm})$ was found as the only deviation in WCRO184

Mitochondrial DNA control region 1 haplotypes were determined for 42 dogs, 135 phenotypic wolves and for 17 suspected hybrids. Four different mtDNA CR1 haplotypes were found in wolves and the same four haplotypes were also found in suspected hybrids. Dogs had 15 different mtDNA CR1 haplotypes and all of them were private, i.e. there was no any mtDNA CR1 haplotype common between the groups of dogs and wolves/ suspected hybrids (Table 3).

The eight genotypic classes simulated in HYBRIDLAB were identified by STRUCTURE with $K=2$. The lower $q$ i values observed in the parental populations were: 


\section{J. Kusak et al.: Wolf-dog hybrids in Croatia}

parental wolves $(\mathrm{PW}) q \mathrm{i}=0.78$; parental dogs $(\mathrm{PD}) q \mathrm{i}=0.721$, whereas the highest values observed in hybrid populations were: first generation hybrids $\left(\mathrm{F}_{1}\right) q \mathrm{i}=0.765$; second generation hybrids $\left(\mathrm{F}_{2}\right) q \mathrm{i}=0.907$; first generation backcrosses with dogs $\left(\mathrm{BC}_{1} \mathrm{D}\right) q \mathrm{i}$ $=0.688$; second generation backcrosses with dogs $\left(\mathrm{BC}_{2} \mathrm{D}\right) q \mathrm{i}=0.729$; first generation backcrosses with wolves $\left(\mathrm{BC}_{1} \mathrm{~W}\right) q \mathrm{i}=0.953$ and second generation backcrosses with wolves $\left(\mathrm{BC}_{2} \mathrm{~W}\right) q \mathrm{i}=0.944$. After running only parental populations in STRUCTURE (with $K=2$, without a priori information, Admixture and $I$ models), the $q$ i values ranged between 0.930 and 0.998 in PW (IC 90\% = 0.654-1.000) and between 0.905 and 0.998 in PD (IC 90\%=0.560-0.993) (Fig. 5).

Table 2. Frequencies of Y-linked microsatellite haplotypes in the wolf (W), dog (D) and suspected hybrid (SH) sample groups. In parenthesis is the total number of analyzed males. Detection of haplotypes in previous studies indicated in the last column: $\mathrm{D}=\operatorname{dogs}, \mathrm{H}=$ hybrids, WHR = Croatian wolves, WBS $=$ wolves from Baltic States, $\mathrm{WCP}=$ wolves from western Carpathians,

$\mathrm{WSC}=$ Scandinavian wolves, $\mathrm{WF}=$ Finland wolves, $\mathrm{WR}=$ Russian wolves, NEW $=$ new haplotype found in this study in dogs.

\begin{tabular}{|c|c|c|c|c|}
\hline Y haplotype ID ${ }^{(1)}$ & $\mathrm{D}(22)$ & $\mathrm{W}(73)$ & SH (10) & Previous studies $^{(2)}$ \\
\hline YH02 & 1 & & & NEW \\
\hline YH06 & 2 & & & D \\
\hline YH07 & 1 & & & WF, WBS, WR \\
\hline YH24 & 1 & & & $\mathrm{D}$ \\
\hline YH25 & 1 & & & NEW \\
\hline YH29 & 1 & & & NEW \\
\hline YH32 & 1 & & & WHR \\
\hline YH34 & 2 & & & D \\
\hline YH05 & 11 & 1 & 2 & $\mathrm{D}, \mathrm{H}, \mathrm{WBS}$ \\
\hline YH08 & 1 & 11 & & WHR, WSC, WBS \\
\hline YH09 & & 10 & & WHR \\
\hline YH19 & & 1 & & WHR \\
\hline YH30 & & 1 & & WHR \\
\hline YH33 & & 1 & & WHR, WBS \\
\hline YH11 & & 15 & 1 & WCP, WHR, WF, WBS, WR \\
\hline YH16 & & 9 & 3 & WCP, WHR, WBS, WR \\
\hline YH18 & & 2 & 1 & WF, WBS, WR \\
\hline YH20 & & 20 & 1 & WHR \\
\hline YH31 & & 2 & 2 & WCP, WHR, \\
\hline Total haplotypes & 10 & 11 & 6 & \\
\hline Private haplotypes & 8 & & \\
\hline
\end{tabular}

${ }^{1}$ - Haplotype identifications as named in (RANDI et al., 2014). ${ }^{2}$ - Y-STR haplotypes found in other studies (SUNDQVIST et al., 2001; IACOLINA et al., 2010; RANDI et al., 2014) 


\section{J. Kusak et al.: Wolf-dog hybrids in Croatia}

Table 3. Frequencies of mtDNA CR1 haplotypes in dogs (D), wolves (W) and suspected hybrids (SH) groups. The number of analyzed individuals is in parenthesis.

\begin{tabular}{|c|c|c|c|}
\hline $\begin{array}{l}\text { mtDNA CR1 } \\
\text { HAPLOTYPES* }\end{array}$ & $\mathrm{D}(42)$ & W (135) & $\mathrm{SH}(17)$ \\
\hline D01 & 7 & & \\
\hline D02 & 7 & & \\
\hline D03 & 8 & & \\
\hline D04 & 1 & & \\
\hline D05 & 1 & & \\
\hline D06 & 4 & & \\
\hline D07 & 3 & & \\
\hline D08 & 1 & & \\
\hline D09 & 1 & & \\
\hline D10 & 1 & & \\
\hline D11 & 2 & & \\
\hline D12 & 1 & & \\
\hline D13 & 3 & & \\
\hline D14 & 1 & & \\
\hline D15 & 1 & & \\
\hline WCR01 & & 50 & 3 \\
\hline WCR02 & & 26 & 2 \\
\hline WCR03 & & 12 & 7 \\
\hline WCR06 & & 47 & 5 \\
\hline Total haplotypes & 15 & 4 & 4 \\
\hline Private haplotypes & & \multicolumn{2}{|c|}{4} \\
\hline
\end{tabular}

* mtDNA CR1 haplotypes identifications as named in (RANDI et al., 2000; GOMERČIĆ et al., 2010).

We used the simulated data to infer information about the power of admixture analyses to detect $F_{1}, F_{2}$ hybrids, the first and second generation of backcrosses, given the number of markers. Considering the STRUCTURE results obtained with the simulated classes of hybrid genotypes, choosing a threshold of 0.78 (lower $q$ i values observed in parental populations) all $\mathrm{F}_{1}$ offspring would be correctly identified as hybrids, but we would miss $4 \%$ of $\mathrm{F}_{2}$ hybrids, then also $34 \%$ of $\mathrm{BC}_{1} \mathrm{~W}$ and $42 \%$ of $\mathrm{BC}_{2} \mathrm{~W}$. Choosing more conservative threshold $q \mathrm{i}=0.90$ (the highest $q \mathrm{i}$ for $\mathrm{F}_{2}$ hybrids), we would correctly identify $100 \%$ of $\mathrm{F}_{1}, \mathrm{~F}_{2}$ hybrids and $96 \% \mathrm{BC}_{1} \mathrm{~W}$ and $94 \% \mathrm{BC}_{2} \mathrm{~W}$, but we would confuse the $13.5 \%$ of wolves as hybrids (false positive as in RANDI et al., 2014. However, any PW showing a $q$ i value $\leq 0.90$, running STRUCTURE using only parental populations and using "population information POPINFO" model the $99 \%$ of PW was correctly identified by both 0.90 and $0.93 q$ i thresholds. Therefore, a threshold of 0.93 was chosen to be used only for classification of individuals with the phenotypic anomalies found. 


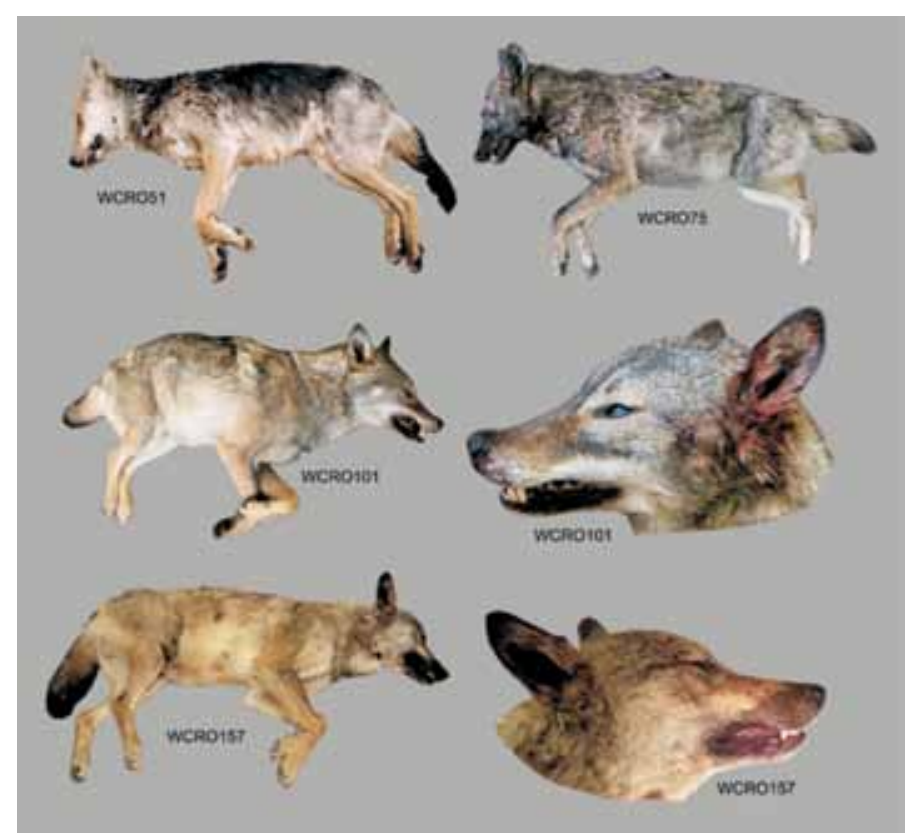

Fig. 4. Wolf-dog hybrids found in Croatia in the period 1996-2011. Combinations of phenotypic anomalies shown include: no black stripes on front legs, dark hairs on the back, too small $(32 \mathrm{~kg})$ for a three year old male (WCRO51), then atypical coloration of hair, rather black head and the body with black patchy areas, particularly on hind legs (WCRO75), head long and narrow, long ears $(11 \mathrm{~cm})$, flat forehead, muzzle (snout) slightly concave (WCRO101) and longer ears (11.4 and $11.5 \mathrm{~cm}$ ), with small paw length (front: 8.6 and $8.1 \mathrm{~cm}$; hind 7.5 and 7.7 ) for a male wolf in the second year of life (WCRO157).

Results from STRUCTURE analyses ( $K=1-5$, Admixture and I models, using Evanno methods), applied to the real sample data, showed that the optimal clustering of samples was obtained with $K=2(\operatorname{Ln} P(D)=-8197,23)$. This divided samples into two distinct clusters corresponding to wolves and dogs, with an average membership proportion of $Q_{\mathrm{W}}=0.990 ;$ IC $90 \%=0.948-1.000$ and $Q_{\mathrm{D}}=0.988$; IC 90\% $=0.928-1.000$. Genotypes were assigned to two clusters with an individual proportion of admixture $q_{\mathrm{W}}$ ranging from 0.77 to 0.998 , and $q_{\mathrm{D}}$ from 0.895 to 0.997 . Suspected hybrids showed a lower $Q_{\mathrm{W}}=$ 0.941 and $q_{\mathrm{W}}$ ranged from 0.281 to 0.998 (Fig. 6). 


\section{J. Kusak et al.: Wolf-dog hybrids in Croatia}

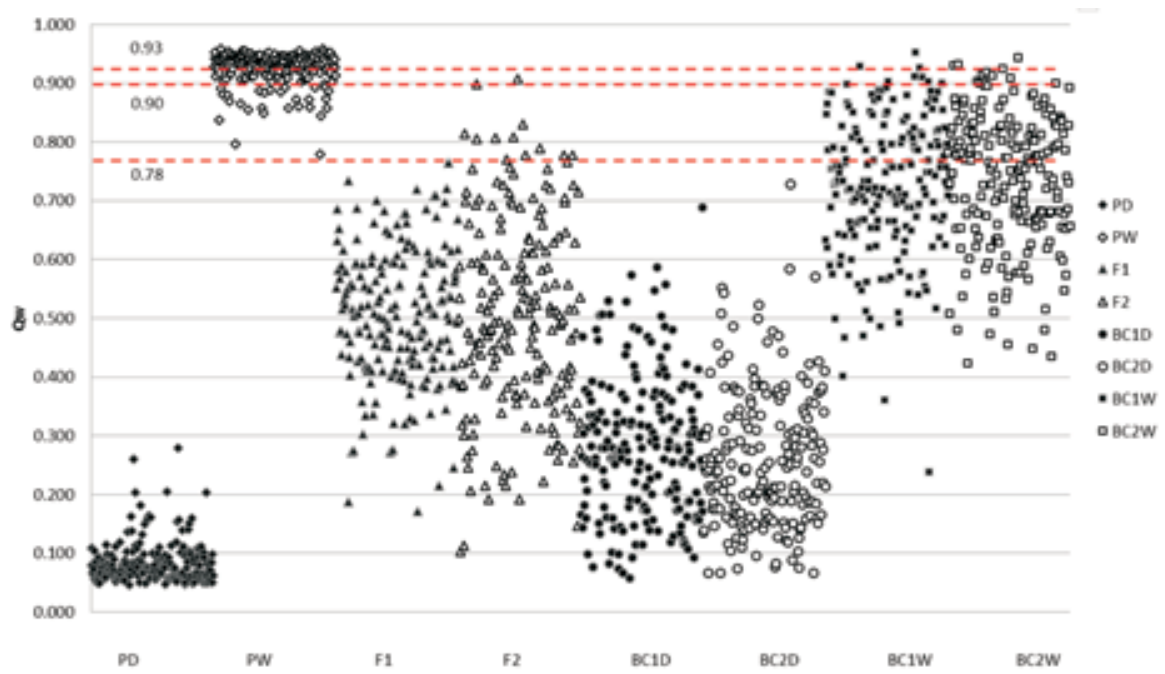

Fig. 5. Eight genotypic classes as the output of simulation in HYBRIDLAB classified by STRUCTURE with $\mathrm{K}=2$. $\mathrm{PD}=$ parental dogs; $\mathrm{PW}=$ parental wolves; $\mathrm{BC}_{1} \mathrm{D}, \mathrm{BC}_{2} \mathrm{D}=$ first and second generation backcross with $\operatorname{dog} ; \mathrm{BC}_{1} \mathrm{~W}, \mathrm{BC}_{2} \mathrm{~W}=$ first and second generation backcross with wolf.

Hybrids identification. The output of STRUCTURE showed that at a threshold of $q \mathrm{i}=0.78$ two individuals were identified as hybrids: WCRO032 and WCRO051, both classified as suspected hybrids on the basis of phenotypic anomalies. Two more individuals (phenotypically suspected hybrids WCRO075, WCRO101) were also identified as genetic hybrids, with a threshold of 0.90 . Finally, using a $q \mathrm{i}=0.93$ (the lowest $q$ i value observed in PW running only parental populations) one more individual (WCRO157) was identified as a wolf-dog hybrid. The detection of hybrid individuals was supported by the IC intervals, i.e. in all genetic hybrids the inferior interval was always $<0.60$. Four hybrids were identified as backcrosses with wolves, while one was identified as a backcross with dogs, but all without the determination of the generation of backcrossing. Four determined hybrids were males, while one was female, but all of them had mtDNA sequences previously found in wolves and not found in dogs from Croatia, i.e. all of the hybrids found were descendants of a female wolf. One individual (WG01) showed a dog Y-haplotype but not any other genetic (12-STR, mtDNA CR1) or phenotypic signal of hybrid origin. This indicates past introgression of dog genes. The remaining 14 suspected hybrids were identified as wolves, considering all three genetic criteria used in the analysis. All five (2.8 percent) identified hybrids were found in the Dalmatia region, while the animal with introgressed dog genes was found in captivity in the Lika region (Fig. 1). 


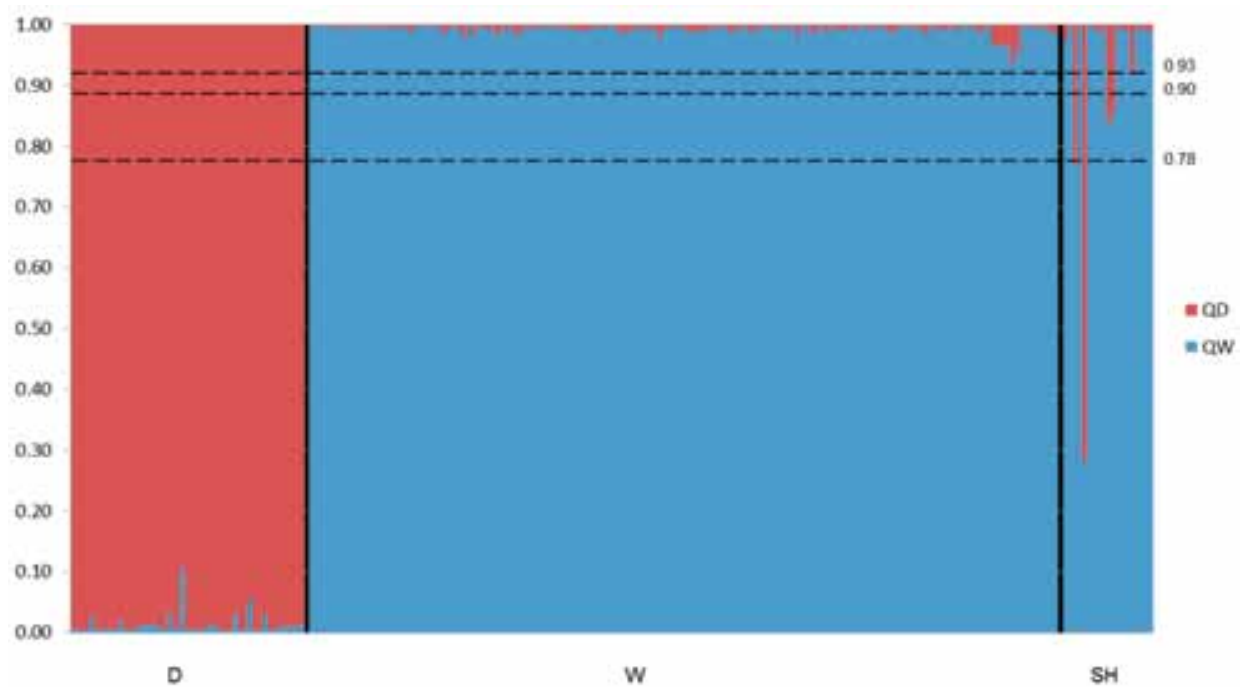

Fig. 6. Posterior probability assignments of $\operatorname{dog}(\mathrm{D})$, wolf (W) and suspected hybrid (SH) in samples genotyped at 12 STRs obtained by STRUCTURE analysis using "admixture" and " $I$ " models without prior population information, $K=2$. Wolf and suspected hybrid individuals were classified on morphometric data and morphological features. Each individual is represented by a vertical bar fragmented in K sections of specific length, according to their proportion of membership in each genetic cluster. The horizontal dotted black lines represent the three chosen thresholds $(0.78 ; 0.90$, and 0.93$)$.

\section{Discussion}

Deviations from the "standard" gray wolf phenotype are sometimes used as a proof of hybridization (MILENKOVIĆ et al., 2006), but in most studies they are just considered the first indication of the possible introgression of dog genes, which are then tested by further genetic analyses (ANDERSONE-LILLEY et al., 2002; CIUCCI et al., 2003; CANIGLIA et al., 2013; KHOSRAVI et al., 2013). We used a combination of 15 distinctive phenotypic features, with three recommended (RANDI et al., 2014) biparental and uniparental classes of genetic markers, to maximize the likelihood of hybrid detection, while minimizing the probability of false hybrids, given the number of autosomal STRs used. The results of STRUCTURE procedures were influenced by the number of populations, by the degree of admixture among them, and the number of autosomal microsatellites used. The shortcoming of the possible identification of false positive hybrids (RANDI et al., 2014) with the use of only 12 autosomal microsatellites, was mitigated by the use of a higher $q i$ threshold for animals with phenotypic deviations. The use of 12 microsatellite STRs was not informative enough for identification of the 


\section{J. Kusak et al.: Wolf-dog hybrids in Croatia}

generations of admixture, they only allowed us to determine if an identified hybrids was a backcross with wolves (BCW), a backcross with dogs (BCD) or a wolf with a past dog gene introgression (IG). The only introgression we found (in WG01) was determined on the basis of the Y chromosome haplotype. The use of phenotypic deviations alone would not be reliable for hybrid detection. Fourteen animals with phenotype deviations were genetically determined as wolves, including two dark and two albino individuals (Table 1. Suspected wolf-dog hybrids and one wolf with introgressed dog genes, found in Croatia in 1996-2011, with a description of the phenotypic anomalies detected. Genetic identification of wolf-dog hybrids and suspected hybrids., Fig. 2 and Fig. 3), while introgressed dog genes were found in one of the phenotypic wolves (WG01).

Two Y-STR haplotypes (YH05 and YH08) were shared among wolves, suspected hybrids and dogs (Table 2). The YH05 haplotype was the most common in dogs, but was found also in two wolves and one putative hybrid (Table 2). In RANDI et al. (2014), YH05 is recognized as a private haplotype found in dog samples of different origin (Italian feral dogs, local dog breeds and Czechoslovakian wolf-dog breed). In IACOLINA et al. (2010) YH05 (named H3) was the most common in dogs but it was also found in five hybrid wolf-dog individuals. The only evidence of YH05 in wolves comes from SUNDQVIST et al. (2001) who found the same haplotype (named L) in four male wolves from Baltic States. In our study, two suspected hybrids carrying YH05 (WCRO32 and WCRO51) were confirmed as hybrids also by their low $q w$, while a third animal with YH05 (WG01) did not show any other (phenotypic, STR or mtDNA CR1) signs of hybridization. These findings could suggest that (1) YH05 is a rare haplotype present in the Croatian wolf population, as in other wolf populations (SUNDQVIST et al., 2001), or (2) YH05 came from a dog and it is a sign of ancient introgression. The haplotype YH08 was found to be quite common in the Croatian wolf population, but the same haplotype was found in one male village dog which showed no apparent traces of admixture with wolves $\left(q_{\mathrm{d}}=0.995\right.$ CI $90 \%=0,976-1,000)$. Haplotype YH08 has been also found in other European wolf populations (Scandinavia and Baltic States) and named C in SUNDQVIST et al. (2001), but never before in dogs. These findings could suggest that (1) YH08 is a rare haplotype also present in domestic dogs; (2) YH08 is private haplotype present in wolf populations, while the dog carrying YH08 was the result of an ancient introgression from the wolf population. If the second hypothesis is true, then this interbreeding and consequent gene introgression included a male wolf and a female dog, which is a possible, but extremely rare event, proven to have happened in only two cases in the world so far: Vancouver Island (MUÑOZ-FUENTES et al., 2010) and Latvia (HINDRIKSON et al., 2012). The common direction of hybridization includes female wolves and male dogs (RANDI et al., 2000; ANDERSONE-LILLEY et al., 2002; VILÀ et al., 2003; VERARDI et al., 2006) and this was reconfirmed by this study. All five proven hybrids shared mtDNA CR1 found in the phenotypic and genotypic wolves determined in this study, and those previously 
found for wolves in Croatia (GOMERČIĆ et al., 2010; SINDIČIĆ et al., 2011). Since mtDNA is inherited by the maternal line only, it is clear that all hybrids found originated from mating between a female wolf and a male dog. Evidence of the opposite direction of hybridization, although it is a rare event (HINDRIKSON et al., 2012), was possibly found in one wolf (WG01), which carried an introgressed dog Y-STR haplotype (YH05). The finding of YH08 in one of the investigated dogs could be more evidence of mating between a male wolf and a female dog. While there are several possible explanations for mating between female wolves and male dogs, the only explanation for the rare opposite direction of mating hypothesized by HINDRIKSON et al. (2012) assumes a low density of female wolves and a high density of stray dogs.

The occurrence of wolf-dog hybrids only in the south of Croatia (Dalmatia, Fig. 1) can be understood by consideration of the history and current status of the wolf population in Croatia, with the accepted conditions for wolf-dog hybridization. Systematic eradication of wolves after WWII caused the range of the wolf population to shrink, with numbers declining to 30-50 individuals in late 1980s (FRKOVIĆ and HUBER, 1992), including their temporary disappearance from Dalmatia. Fortunately, this smal number of wolves were never isolated from the rest of the Dinaric-Balkan wolf population and the bottleneck effect was not as severe as in some other European wolf populations (ARBANASIĆ et al., 2013; FABBRI et al., 2014). At the beginning of the 1990s, the number of wolves started to grow, with the expansion of their range back to Dalmatia and some other parts of Croatia (KUSAK and HUBER, 2010a). Wolves in Dalmatia live in close proximity to humans (KUSAK et al., 2005), largely depending on human food sources (ŠTRBENAC et al., 2005), which causes human animosity toward wolves (MAJIĆ and BATH, 2010) and consequent high human-caused mortality rates (KUSAK and HUBER, 2010b). Since the chances for wolf-dog hybridization increase when wolves live close to settlements with a high density of dogs (BLANCO et al., 1992), as well as in situations when wolves are heavily victimized (RANDI et al., 2000) or during the expansion phase of the wolf population (LORENZINI et al., 2014; RANDI et al., 2014), it seems that the prevalence of hybrids found in Dalmatia (five out of $85,5.9 \%$ ) was surprisingly low, considering that all the listed conditions for hybridization were met. VILÀ and WAYNE (1999) summarized that hybridization between gray wolves and domestic dogs is unusual and even if it happens, the offspring of male dogs and female wolves may rarely survive because male dogs provide limited parental care, rendering such events insignificant for the genetic composition of the gray wolf population. However, examples of introgression of dog genes into wolf populations, such as the presence of black wolves in North America (ANDERSON et al., 2009) and Italy (CANIGLIA et al., 2013), has been proven to persist in wolf populations, since it gives higher life expectancy to individuals carrying these genes, resulting in positive selection under the current environmental changes (COULSON et al., 2011). Two dark haired suspected hybrids in this study did not show 
genetic signs of hybridization, but they were not checked for melanistic mutation at the $K$ locus, determining black coloration in wolves (ANDERSON et al., 2009). The presence of YH05 haplotype was found as the only sign of the past introgression of dog genes into the Dinaric wolf population, but even if introgression happens more often than could be detected with the methodology used, the ecological importance of this process remains largely unknown. The only study of trophic overlap between wolves and freeranging wolf-dog hybrids (BASSI et al., 2017) proved that hybrids can live as wolves and be equal competitors for food as pure wolves with each other. With such diverse and unpredictable effects of hybridization, it is difficult to render unambiguous legislative, conservation and management decisions. The Convention on International Trade in Endangered Species (CITES, Conf. 10.17, Rev. Cop14) gives the same level of protection to hybrids as to wild species. Croatian nature conservation law (Official Gazette 80/13) lists equally wolves and their hybrids as strictly protected. Evidence of past hybridization and introgression of dog genes, such as black, yellow or patchy coat coloration, dewclaw (CIUCCI et al., 2003), dental anomalies etc., raises question if such animals should be removed (lethal or live removal) from the population, and if so, how and under which conditions (LESCUREUX and LINNELL, 2014). As proven by this study, distinguishing wolves from hybrids by their external appearance is unreliable, and even if distinction is done genetically, as pointed out by LESCUREUX and LINNELL (2014), the question is where to set the threshold of (un)acceptable introgression. More studies are needed on the frequency of hybridization events and the circumstances resulting in wolf-dog hybrids, in addition to studies on the behavior and ecology of hybrids. These studies are necessary to support sound conservation and management decisions. The prevalence of hybridization in Croatia was found to be lower compared to Italy ( 2.8 vs. 6.5 percent; LORENZINI et al., 2014), but as LORENZINI et al. (2014) warned, the proportion of hybrids, and consequently the perception of how severe the hybridization is, depends on the detection power of the marker set and the threshold selected for assigning genotypes. It is possible that with the use of a larger number of autosomal microsatellites, we would achieve different results. Nevertheless, hybridization between wolves and dogs exists in Croatia and is expected to persist as long as the conditions favoring its occurrence are met. The ecological, sociological and conservation implications of hybridization are yet to be determined and considered in the future management of the species.

\footnotetext{
Acknowledgements

This study was undertaken with the financial aid of the Croatian Agency for Nature and Environment, Croatian Environment Fund, Bernd Thies Foundation, UK Wolf Conservation Trust, EURONATUR, Paradise Wildlife Park, "Sjeverni Velebit" National Park, "Velebit" Nature Park and "Plitvice Lakes" National Park. We thank all inspectors for their assessment of damage by protected species, members of the Large Carnivores Emergency Team of Croatia, game wardens and all others who helped collect the bodies of dead wolves.
} 


\section{J. Kusak et al.: Wolf-dog hybrids in Croatia}

\section{References}

ANDERSON, T. M., B. M. VONHOLDT, S. I. CANDILlE, M. MUSIANI, C. GRECO, D. R. STAHLER, D. W. SMITH, B. PADHUKASAHASRAM, E. RANDI, J. a. LEONARD, C. D. BUSTAMANTE, E. A. OSTRANDER, H. TANG, R. K. WAYNE, G. S. BARSH (2009): Molecular and evolutionary history of melanism in North American gray wolves. Science 323, 1339-1343.

ANDERSONE-LILLEY, Z., V. LUCCHINI, E. RANDI, J. OZOLINS (2002): Hybridisation between wolves and dogs in Latvia as documented using mitochondrial and microsatellite DNA markers. Mamm. Biol. 67, 79-90.

ARBANASIĆ, H., D. HUBER, J. KUSAK, T. GOMERČIĆ, J. HRENOVIĆ, A. GALOV (2013): Extensive polymorphism and evidence of selection pressure on major histocompatibility complex DLA-DRB1, DQA1 and DQB1 class II genes in Croatian grey wolves. Tissue Antigens 81, 19-27.

BASSI, E., A. CANU, I. FIRMO, L. MATTIOLI, M. SCANDURA, M. APOLLONIO (2017): Trophic overlap between wolves and free-ranging wolf $\times$ dog hybrids in the Apennine Mountains, Italy. Glob. Ecol. Conserv. 9, 39-49.

BLANCO, J. C., S. REIG, L. DE LA CUESTA (1992): Distribution, status and conservation problems of the wolf Canis lupus in Spain. Biol. Conserv. 60, 73-80.

BOITANI, L. (2003): Wolf conservation and recovery. In: Wolves. Behavior, Ecology, and Conservation (Mech, L. D., L. Boitani, Eds.), Chicago and London, The University of Chicago Press, pp. 317-340.

CANIGLIA, R., E. FABBRI, C. GRECO, M. GALAVERNI, L. MANGHI, L. BOITANI, A. SFORZI, E. RANDI (2013): Black coats in an admixed wolf $\times$ dog pack is melanism an indicator of hybridization in wolves? Eur. J. Wildl. Res. 59, 543-555.

CIUCCI, P., V. LUCCHINI, L. BOITANI, E. RANDI (2003): Dewclaws in wolves as evidence of admixed ancestry with dogs. Can. J. Zool. 81, 2077-2081.

COULSON, T., D. R. MACNULTY, D. R. STAHLER, R. K. WAYNE, D. W. SMITH, OTHERS (2011): Modeling effects of environmental change on wolf population dynamics, trait evolution, and life history. Science 334, 1275-1278.

FABBRI, E., R. CANIGLIA, J. KUSAK, A. GALOV, T. GOMERČIĆ, H. ARBANASIĆ, D. HUBER, E. RANDI (2014): Genetic structure of expanding wolf (Canis lupus) populations in Italy and Croatia, and the early steps of the recolonization of the Eastern Alps. Mamm. Biol. 79, 138-148.

FALUSH, D., M. STEPHENS, J. K. PRITCHARD (2007): Inference of population structure using multilocus genotype data: Dominant markers and null alleles. Mol. Ecol. Notes 7, 574-578.

FREEDMAN, A. H., I. GRONAU, R. M. SCHWEIZER, D. ORTEGA-DEL VECCHYO, E. HAN, P. M. SILVA, M. GALAVERNI, Z. FAN, P. MARX, B. LORENTE-GALDOS, H. BEALE, O. RAMIREZ, F. HORMOZDIARI, C. ALKAN, C. VILÀ, K. SQUIRE, E. GEFFEN, J. KUSAK, A. R. BOYKO, H. G. PARKER, C. LEE, V. TADIGOTLA, A. SIEPEL, C. D. BUSTAMANTE, T. T. HARKINS, S. F. NELSON, E. A. OSTRANDER, T. MARQUES- 


\section{J. Kusak et al.: Wolf-dog hybrids in Croatia}

BONET, R. K. WAYNE, J. NOVEMBRE (2014): Genome sequencing highlights the dynamic early history of dogs. PLoS Genet. 10, e1004016.

FRKOVIĆ, A., Đ. HUBER (1992): Wolves in Croatia: baseline data. In: Proceedings of the Workshop: Wolves in Europe - Current status, Prospects Oberammergau, Germany, Oberammergau, Germany, pp. 67-69.

GOMERČIĆ, T., M. SINDIČIĆ, A. GALOV, H. ARBANASIĆ, J. KUSAK, I. KOCIJAN, M. ĐURAS GOMERĆIĆ, Đ. HUBER (2010): High genetic variability of the grey wolf (Canis lupus L.) population from Croatia as revealed by mitochondrial DNA control region sequences. Zool. Stud. 49, 816-823.

HINDRIKSON, M., P. MÄNNIL, J. OZOLINS, A. KRZYWINSKI, U. SAARMA (2012): Bucking the trend in wolf-dog hybridization: first evidence from Europe of hybridization between female dogs and male wolves. PLoS One 7, 1-12.

HUBER, Đ., J. KUSAK, A. FRKOVIĆ, G. GUŽVICA, T. GOMERČIĆ (2002): Causes of wolf mortality in Croatia in the period 1986-2001. Vet. arhiv 72, 131-139.

IACOLINA, L., M. SCANDURA, A. GAZZOLA, N. CAPPAI, C. CAPITANI, L. MATTIOLI, F. VERCILLO, M. APOLLONIO (2010): Y-chromosome microsatellite variation in Italian wolves: A contribution to the study of wolf-dog hybridization patterns. Mamm. Biol. 75, 341347.

KHOSRAVI, R., H. R. REZAEI, M. KABOLI (2013): Detecting hybridization between Iranian wild wolf (Canis lupus pallipes) and free-ranging domestic dog (Canis familiaris) by analysis of microsatellite markers. Zoolog. Sci. 30, 27-34.

KUSAK, J. (2010): Wolf movements and pack structure. In: Management Plan for Wolves in Croatia (Štrbenac, A., Ed.). State Institute for Nature Protection, Zagreb, pp. 21-26 (in Croatian).

KUSAK, J., Đ. HUBER (2010a): Dynamics, number and trend of wolf population from 1992. to 2008. In: Management Plan for Wolves in Croatia (Štrbenac, A., Ed.): State Institute for Nature Protection, Zagreb, pp. 19-21 (in Croatian).

KUSAK, J., Đ. HUBER (2010b): Causes and dynamics of wolf mortality in the period from 1945 to 2008. In: Management Plan for Wolves in Croatia (Štrbenac, A., Ed.): State Institute for Nature Protection, Zagreb, pp. 44-50 (in Croatian).

KUSAK, J., A. M. SKRBINŠEK, D. HUBER (2005): Home ranges, movements, and activity of wolves (Canis lupus) in the Dalmatian part of Dinarids, Croatia. Eur. J. Wildl. Res. 51, 254262.

LESCUREUX, N., J. D. C. LINNELL (2014): Warring brothers: The complex interactions between wolves (Canis lupus) and dogs (Canis familiaris) in a conservation context. Biol. Conserv. $171,232-245$.

LORENZINI, R., R. FANELLI, G. GRIFONI, F. SCHOLL， R. FICO (2014): Wolf-dog crossbreeding: "Smelling" a hybrid may not be easy. Mamm. Biol. 79, 149-156.

MAJIĆ, A., A. J. BATH (2010): Changes in attitudes toward wolves in Croatia. Biol. Conserv. 143, 255-260.

Vet. arhiv 88 (3), 375-395, 2018 


\section{J. Kusak et al.: Wolf-dog hybrids in Croatia}

MILENKOVIĆ, M., V. HABIJAN-MIKEŠ, R. MATIĆ (2006): Cases of spontaneous interbreeding of wolf and domestic dog in the region of Southeast Banat (Serbia). Arch. Biol. Sci. 58, 225231.

MUÑOZ-FUENTES, V., C. T. DARIMONT, P. C. PAQUET, J. A. LEONARD (2010): The genetic legacy of extirpation and re-colonization in Vancouver Island wolves. Conserv. Genet. 11, 547-556.

NIELSEN, E. E., L. A. BACH, P. KOTLICKI (2006): HYBRIDLAB (version 1.0): A program for generating simulated hybrids from population samples. Mol. Ecol. Notes 6, 971-973.

PLATIŠA, M., I. PINTAR, J. KUSAK (2011): Body features of gray wolf (Canis lupus L.). Veterinar 49, 16-27 (in Croatian).

RANDI, E., P. HULVA, E. FABBRI, M. GALAVERNI, A. GALOV, J. KUSAK, D. BIGI, B. Č. BOLFÍKOVÁ, M. SMETANOVÁ, R. CANIGLIA (2014): Multilocus detection of wolf $\times \operatorname{dog}$ hybridization in Italy, and guidelines for marker selection. PLoS One 9, e86409.

RANDI, E., V. LUCCHINI (2002): Detecting rare introgression of domestic dog genes into wild wolf (Canis lupus) populations by Bayesian admixture analyses of microsatellite variation. Conserv. Genet. 3, 31-45.

RANDI, E., V. LUCCHINI, M. F. CHRISTENSEN, N. MUCCI, S. M. FUNK, G. DOLF, V. LOESCHCKE (2000): Mitochondrial DNA variability in Italian and east European wolves: Detecting the consequences of small population size and hybridization. Conserv. Biol. 14, 464-473.

SINDIČIĆ, M., T. GOMERČIĆ, A. GALOV, H. ARBANASIĆ, J. KUSAK, A. SLAVICA, Đ. HUBER (2011): Mitochondrial DNA control region as a tool for species identification and distinction between wolves and dogs from Croatia. Vet. arhiv 81, 249-258.

SKOGLUND, P., E. ERSMARK, E. PALKOPOULOU, L. DALEN (2015): Ancient wolf genome reveals an early divergence of domestic dog ancestors and admixture into high-latitude breeds. Curr. Biol.1515-1519.

SUNDQVIST, A.-K., H. ELLEGREN, M. OLIVIER, C. VILÀ (2001): Y chromosome haplotyping in Scandinavian wolves (Canis lupus) based on microsatellite markers. Mol. Ecol. 10, 19591966.

ŠTRBENAC, A., Đ. HUBER, J. KUSAK, A. MAJIĆ SKRBINŠEK, A. FRKOVIĆ, Ž. ŠTAHAN, J. JEREMIĆ-MARTINKO, S. DESNICA, P. ŠTRBENAC (2005): Wolf management plan for Croatia. State Institute for Nature Protection Zagreb, p. 110 (in Croatian).

ŠTRBENAC, A., J. KUSAK, Đ. HUBER, J. JEREMIĆ, P. OKOVIĆ, A. MAJIĆ-SKRBINŠEK, I. VUKŠIĆ, L. KATUŠIĆ, S. DESNICA, T. GOMERČIĆ, A. BIŠĆAN, D. ZEC, M. GRUBEŠIĆ (2010): Management plan for wolves in Croatia for the period 2010 - 2015. State Institute for Nature Protection. Zagreb, p. 136 (in Croatian).

VÄHÄ, J., C. R. PRIMMER (2006): Efficiency of model-based Bayesian methods for detecting hybrid individuals under different hybridization scenarios and with different numbers of loci. Mol. Ecol. 15, 63-72. 
VERARDI, A., V. LUCCHINI, E. RANDI (2006): Detecting introgressive hybridization between free-ranging domestic dogs and wild wolves (Canis lupus) by admixture linkage disequilibrium analysis. Mol. Ecol. 15, 2845-2855.

VILÀ, C., C. WALKER, K. SUNDQViST, Ø. FLAGSTAD, Z. ANDERSONE, CASULLI, I. KOJOLA, H. VALDMANN, J. HALVERSON, H. ELLEGREN (2003): Combined use of maternal, paternal and bi-parental genetic markers for the identification of wolf-dog hybrids. Heredity (Edinb). 90, 17-24.

VILÀ, C., R. K. WAYNE (1999): Hybridization between wolves and dogs. Conserv. Biol. 13, 195198.

WAYNE, R. K., E. GEFFEN, D. J. GIRMAN, K. P. KOEPFLI, L. M. LAU, C. R. MARSHALL (1997): Molecular systematics of the Canidae. Syst. Biol. 46, 622-646.

Received: 14 March 2017

Accepted: 10 April 2017

\section{KUSAK, J., E. FABBRI, A. GALOV, T. GOMERČIĆ, H. ARBANASIĆ, R. CANIGLIA, M. GALAVERNI, S. RELJIĆ, DJ. HUBER, E. RANDI: Križanje vukova i pasa u Hrvatskoj. Vet. arhiv 88, 375-395, 2018. \\ SAŽETAK}

Križanje vukova i pasa jedna je od glavnih prijetnji očuvanju vukova jer se miješanjem i introgresijom gena domaćih životinja mogu narušiti lokalne prilagodbe te tako ugroziti dugoročni opstanak populacija vukova u prirodi. Istražili smo pojavu križanja vukova i pasa u Hrvatskoj analizom 12 autosomskih mikrosatelitskih markera Bayesian testom primjese te utvrdili smjer hibridizacije određivanjem markera nasljeđivanih i po majčinskoj i po očinskoj liniji, u kombinaciji s određivanjem morfometrijskih i morfoloških svojstava. Sustavna analiza morfoloških svojstava i morfometrijskih podataka korištena je za rangiranje istraživanih jedinki, bilo kao fenotipske divlje tipove vukova bilo kao sumnjive na križanost. Kombiniranjem rezultata Bayesian statistike s fenotipskim obilježjima postavili smo prag za razlikovanje vukova od križanaca, koji povećava vjerojatnost određivanja križanaca uz smanjivanje vjerojatnosti za pogrešno pozitivno određivanje. Temeljem fenotipa, od 176 divljih kanida 157 (89,2 \%) bilo je kategorizirano kao vukovi, dok je 19 (10,8 \%) bilo svrstano u sumnjive križance. Temeljem Bayesian testa primjese, pet (2,8 \%) životinja bilo je svrstano u križance vuka i psa, četiri od njih određena su kao unatražno križani s vukovima, dok je jedan bio unatražno križan sa psom. Mitohondrijska DNK pokazala je da su svi križanci bili rezultat parenja vučice sa psom. Dva su muška križanca na Y-kromosomu imala haplotipove i od vukova i od pasa, dok su druga dva imala Y-kromosomske haplotipove dosad utvrđene samo kod vukova. Jedan je vuk imao pseći Y-kromosomski haplotip što je uputilo na introgresiju psećih gena. Svi su križanci pronađeni u Dalmaciji, gdje su se vukovi nedavno proširili te gdje žive blizu ljudi, s visokom stopom smrtnosti uzrokovane od ljudi. Te se okolnosti inače smatraju pogodujućima za nastanak križanaca vukova i pasa. Ipak, pronađena učestalost pojave križanaca bila je niska, ali i za očekivati je da će se zadržati sve dok postoje uvjeti koji pogoduju nastanku križanaca. Ekološke, sociološke te značajke hibridizacije za zaštitu i upravljanje populacijom vukova tek treba utvrditi.

Ključne riječi: vuk; pas; Canis lupus; križanje; Hrvatska; Bayesijska analiza primjese; mikrosateliti; roditeljski markeri 
